\title{
Programmable low-cost DNA-based platform for viral RNA detection
}

\author{
Lifeng Zhou', Arun Richard Chandrasekaran ${ }^{1,+}$, Jibin Abraham Punnoose ${ }^{1, \dagger}$, Gaston Bonenfant ${ }^{1,2}$, Stephon \\ Charles $^{1,2}$, Oksana Levchenko ${ }^{1}$, Pheonah Badu ${ }^{1,2}$, Cassandra Cavaliere ${ }^{1,2}$, Cara T. Pager ${ }^{1,2, *}$ and Ken Halvorsen ${ }^{1, *}$ \\ ${ }^{1}$ The RNA Institute, University at Albany, State University of New York, Albany, NY 12222, USA. ²Department of Biology, University at Albany, State University of New York, \\ Albany, NY 12222, USA. \\ tThese authors contributed equally to this work. \\ *Corresponding authors. Email: ctpager@albany.edu or khalvorsen@albany.edu
}

Detection of viruses is critical for controlling disease spread. Recent emerging viral threats including Zika virus, Ebola virus, and SARS-Cov-2 (responsible for COVID-19) highlight the cost and difficulty in responding rapidly. To address these challenges, we develop a platform for low-cost and rapid detection of viral RNA with DNA nanoswitches that mechanically reconfigure in response to specific viruses. Using Zika virus as a model system, we show non-enzymatic detection of viral RNA, with selective and multiplexed detection between related viruses and viral strains. For clinical-level sensitivity in biological fluids, we paired the assay with sample preparation using either RNA extraction or isothermal pre-amplification. Our assay requires minimal lab infrastructure, and is adaptable to other viruses, as demonstrated by quickly developing DNA nanoswitches to detect SARS-CoV-2 RNA in saliva. We expect further development and field implementation will improve our ability to detect emergent viral threats and ultimately limit their impact.

\section{Introduction}

Newly emerging or re-emerging viruses pose significant challenges to health care systems, particularly as globalization has contributed to the rampant spread of these viruses (1). RNA viruses are frequently the cause of sweeping outbreaks as these viruses have high mutation rates and thus evolve rapidly $(2,3)$. Examples of this include the annual influenza outbreak, Ebola virus, Zika virus (ZIKV) and the SARS-CoV-2 virus responsible for the COVID-19 pandemic. Technological advancements in structural biology and genomics have been important for identifying viruses, and for advancing fundamental viral research and antiviral therapeutics (4). However, clinical methods for robust, low-cost and rapid detection of viral infections remain a major challenge for emergent viruses, especially in resource limited areas.

Detection of RNA viruses in the clinical setting is typically performed using either immunological detection based on enzyme-linked immunosorbent assay (ELISA) to detect IgM antibodies or nucleic acid testing (NAT) based on a reverse transcription polymerase chain reaction (RT-PCR) assay to detect viral RNA (5-8). Diagnosing RNA viruses is made challenging by several factors including a limited time window for detection, low or varying viral load, cross-reactive IgM antibodies, and laboratory resources. The detection time windows can vary widely from as short as a few days to as long as several months (5), and molecular detection techniques are usually most reliable if performed within the first two weeks of the disease $(9,10)$. Depending on the timing of testing relative to infection, even highly sensitive NAT assays may still produce false negative or false positive results (6). On the other hand, results from IgM serology tests often cannot distinguish related viruses or different strains of the same virus due to cross-reactivity of IgM antibodies, thus leading to false positive results $(11,12)$. These detection challenges are further exacerbated when outbreaks occur in low resource settings where infrastructure for these lab-intensive tests can be lacking, accelerating the spread of disease $(7,13)$.

In response to some of these challenges, new techniques are being developed to detect emerging viruses. Among these are methods that adopt nanoparticles (14), graphene-based biosensors (15), and CRISPR-based methods $(16,17)$, to name a few. Many of these proposed strategies, although based on cutting-edge technology, require multiple reactions or signal transformation steps. Here, we addressed these biosensing challenges by developing an assay that uses programmable DNA nanoswitches (18) for detection of viral RNA at clinically relevant levels. We validate our viral RNA detection strategy using ZIKV as a model virus. Zika has high global health relevance and is a continued threat due to its re-emerging mosquito-borne nature. Although ZIKV infections are typically associated with mild symptoms, they have been linked to devastating birth defects associated with intrauterine infections, development of Guillian-Barré syndrome in adults, and the possibility of sexual transmission $(7,10)$. Moreover, despite 
significant advances in understanding the molecular biology of ZIKV, there is still a lack of antiviral drugs and vaccines, making robust detection of ZIKV vital to controlling the spread of the disease and implementing early treatments (19).

Our strategy for detecting the presence of viral RNA is based on using DNA nanoswitches that have been designed to undergo a conformational change (from linear to looped) upon binding a target viral RNA (Fig. 1A). The presence of the viral RNA would be indicated by shifted migration of the looped nanoswitch by gel electrophoresis. Importantly, the system is designed to use common nucleic acid staining of the nanoswitch itself that can intercalate thousands of dye molecules to provide an inherently strong signal. Previously, we demonstrated sensitive and specific detection of DNA oligonucleotides (20) and microRNAs ( 22 nucleotides long) (21) using this approach. Applied here to viral RNA detection, we solve many challenges of detecting a long viral RNA (>10,000 nucleotides) in clinically relevant samples. We develop an RNA fragmentation strategy, a novel signal multiplication strategy, a custom algorithm for choosing target sequences, and new workflows for measuring viral loads in biological and mock clinical samples with or without RNA pre-amplification. Using this approach, we show how multiplexing can be used to detect multiple viruses simultaneously from a single sample and demonstrate high specificity even between closely related strains of Zika. In response to the COVID-19 pandemic, we quickly developed and validated DNA nanoswitches (Fig. 1B) for the detection of SARS-CoV-2 RNA spiked into human saliva. Our approach is inherently non-enzymatic but can optionally be combined with an isothermal amplification step, allowing use in low resource areas (Fig. 1C). This work enables direct detection of viral RNA without amplification and paves the way toward a low-cost assay for detection of RNA viruses.

\section{Results}

As a first proof-of-concept for detecting ZIKV, we designed DNA nanoswitches to target an already validated sequence in the ZIKV genome that has been used to bind primers in qPCR (22) (all oligo sequences are specified in Tables S1 to S10). We made the DNA nanoswitches by hybridizing single-stranded DNA (ssDNA) oligos to linearized single-stranded M13mp18 (M13) genomic DNA in a thermal annealing ramp for 1 hour (18) and purified them by high-performance liquid chromatography (HPLC) (23). For our initial detection target, we in vitro transcribed RNA from the pFLZIKV infectious plasmid containing the full-length genome of the Cambodia ZIKV isolate (FSS13025) (fig. S1) (24). Previous results have shown robust nanoswitch detection of small DNA and RNA sequences (20-30 nucleotides), but the long viral RNA is expected to have strong secondary structures that may interfere with our detection (25). To overcome this, we used a chemical fragmentation method to segment the RNA into small pieces that are mostly shorter than 200 nucleotides (Fig. 2A-B and fig. S2). By incubating with our nanoswitch in an annealing temperature ramp, we showed successful detection of the fragmented viral RNAs by gel electrophoresis, thus validating our approach (Fig. 2C).

Having shown successful detection of ZIKV RNA using a single target sequence, we recognized that we could exploit the large genome size $(\sim 11,000$ nucleotides) to increase our detection signal through multiple targets. Once the long viral RNA is fragmented, the number of available target sequences increases dramatically. Since our detection signal is proportional to the number of looped nanoswitches, a nanoswitch mixture for different target sequences within the viral genome is expected to provide an increased signal. To test this, we developed an algorithm for choosing multiple sequence regions in the viral genome that can be targeted by the nanoswitches (Note S1). First, we chose the default target length as 30 nucleotides based on results from screening nanoswitches with different detection arm lengths (fig. S3). Then, the algorithm selectively excluded target sequences that could form stable secondary structures (fig. S4) and cross-binding with nanoswitch backbone oligos (fig. S5), and enforced GC content and uniqueness of sequences. Based on these criteria, we chose 18 target regions along the entire ZIKV RNA for testing and designed the nanoswitches. To facilitate use of our Matlab-based software, we have built a graphical user interface (fig. S6) and made it freely available (File S1).

We then validated quality and function of each nanoswitch in the panel of 18 nanoswitches. All nanoswitches performed well with a molar excess of positive DNA controls (20:1 DNA control to nanoswitch), although they showed more signal variation with fragmented ZIKV RNA (fig. S7). We ranked the nanoswitches from strongest to weakest signal and made a series of equimolar nanoswitch mixtures. Using these mixtures, we validated our inherent signal multiplication strategy using a low concentration pool of equimolar DNA fragments to mimic the fragmented RNA. We observed that our detection signal increased steadily up to around 12 different nanoswitches (Fig. 2D-E), and then plateaued above that value. This plateau was not unexpected considering that the largest mixtures added lower performing nanoswitches that may contribute less to the overall sample. Since there was no significant change in performance between 12 and 18, we continued using the 18 nanoswitches mix for our follow up experiments.

High sensitivity is one of the key requirements for virus detection. Clinical levels of ZIKV RNA in body fluids of infected patients are often in the femtomolar range $(7,17,26)$, making amplification a prerequisite for most detection approaches. Based on our earlier observation that DNA 
nanoswitches can detect microRNAs ( 22 nucleotides) in the sub-picomolar scale (21) without amplification, we wanted to assess the sensitivity of our approach for ZIKV RNA detection. We reacted the DNA nanoswitch mixture with different amounts of fragmented RNA in a 12-hour annealing temperature ramp from $40^{\circ} \mathrm{C}$ to $25^{\circ} \mathrm{C}$. The results showed visible detection for ZIKV RNA as low as $12.5 \mathrm{pg}$ ( $\sim 3.5$ attomole or $\sim 2.1 \times 10^{6}$ copies) in a $10 \mu \mathrm{l}$ reaction volume (Fig. $2 \mathrm{~F}$ and fig. S8). Consistent with Fig. 2E, the approach based on using a nanoswitch mix outperformed the highest performing nanoswitch used as a single agent, which had visible detection to about $50 \mathrm{pg}$ ( $\sim 14$ attomole) (fig. S9).

Another key requirement for a clinical virus detection assay is specificity. Since ZIKV and Dengue virus (DENV) have overlapping geographical distributions and clinical symptoms, infection with either virus may result in clinical misdiagnosis (27). Serological diagnostic assays are known to show antibody cross-reactivity between the two viruses, and DENV has some similarity to ZIKV in its envelope protein (11) and genome sequence $(17,25)$. To test the specificity of our approach, we designed a similar panel of nanoswitches to detect DENV (fig. S10). Using the pooled nanoswitches specific for ZIKV and DENV, we mixed each set with in vitro transcribed RNA from each virus and found perfect specificity, with each assay only detecting its correct target RNA (Fig. 3A). Using the programmability of the nanoswitch, we further demonstrated a multiplexed system for simultaneous detection of ZIKV and DENV. In this case we modified the DENV responsive nanoswitches to form a smaller loop size (fig. S11), causing two distinct detection bands to migrate to different positions in the gel. Specifically, ZIKV RNA-nanoswitch complex migrated slower/higher in the gel, while the complex of DENV RNA and the nanoswitch migrated faster/lower in the gel (Fig. 3B). Therefore, in a single reaction our nanoswitch showed differential and specific detection of ZIKV and DENV RNA. By programming different loop sizes for different targets, this assay can be expanded for up to five viral targets (21).

In addition to possible misdiagnosis between different viruses, there is an additional challenge in determining the specific strain of a virus. For example, in Latin America four different DENV serotypes are known to be present and co-circulate, where misdiagnosis of the infecting strain can have significant implications for treatment options (28). Thus, being able to accurately identify a circulating strain of virus broadly impacts medical care, surveillance and vector control (29). ZIKV was first identified in Uganda in 1947 before spreading to Asia and the Americas, and ZIKV strains (classified within African or Asian lineage) share significant sequence homology (30). To investigate if our assay can distinguish between the Asian and African lineages, we tested our nanoswitches against two ZIKV strains which have $\sim 89 \%$ sequence homology, namely the FSS13025 isolated from Cambodia and the MR766 strain isolated from Uganda. In designing the ZIKV strain-specific nanoswitches, we identified five target regions that each have a 5-6 nucleotide difference (Fig. 3C and fig. S12). To achieve better discernment of the detection signal, the nanoswitches for the Uganda strain were designed to form a smaller loop-size than those designed for Cambodia. Next, a human hepatocellular carcinoma cell line (Huh7) was infected with either the Cambodian or Ugandan ZIKV strain. Infected cells were processed to extract total RNA, which was then fragmented and incubated with nanoswitches to probe for viral RNA from either the ZIKV Cambodia or ZIKV Uganda infected cells. The results showed that our assay was able to discriminate between two strains of the same virus even with high genetic similarities (Fig. 3D and fig. S12).

Further applying our technique to detect ZIKV RNA in biological samples, we either mock-infected or infected Huh7 cells with the Cambodia ZIKV strain at a multiplicity of infection of 1 and extracted RNA from the ZIKV infected cells at 1-, 2- and 3-days post-infection (31). The nanoswitch assay detected ZIKV viral RNA from the infected cells but not the mock infected cells (Figs. 4A-B and fig. S13). Our detection result showed that the copies of ZIKV RNA within infected cells steadily increased upon the infection and plateaued at 2- and 3-days post-infection (Fig. 4C). These data demonstrate that our assay can detect ZIKV RNA in infected cell lines, and in contrast to typical RT-PCR assays without amplification of the viral RNA.

Moving toward clinical applications, we aimed to demonstrate detection of relevant levels of ZIKV RNA from biological fluids. ZIKV is present in the serum, urine, and other body fluids of infected patients (32). The viral loads can vary dramatically between individuals, body fluid, and post infection time $(6,7)$, but are frequently in the sub-femtomolar to femtomolar range, with ZIKV in human urine reported as high as $220 \times 10^{6}$ copies/ml (365 fM) (26). While our nanoswitch sensitivity for in vitro transcribed viral RNA in buffer approaches clinically relevant concentrations, detection from body fluids is further challenged by varying viral loads and by body fluids that can reduce the performance of the nanoswitches due to physiological conditions and nuclease activity $(20,33)$. To overcome these potential difficulties, we investigated two independent solutions: 1) adding a preprocessing step to extract RNA from body fluids such as urine, or 2) adding an isothermal pre-amplification step. In the first approach, we spiked a clinically relevant amount of in vitro transcribed ZIKV RNA into human urine and processed viral RNA extraction using a commercial RNA extraction kit. RNase inhibitors were included to minimize RNA degradation in urine. We then mixed the extracted RNA with the nanoswitches and demonstrated non-enzymatic, clinical level detection of the RNA at $1.7 \times 10^{5}$ copies $/ \mu l(0.28 \mathrm{pM})$ (Fig. 
5A and fig. S14). In the second approach, we demonstrated that our detection can be coupled with other amplification approaches such as nucleic acid sequence-based amplification (NASBA) (34). NASBA combines multiple enzymes and primers to achieve RNA amplification in a one-pot isothermal reaction (fig. S15A). First, we showed feasibility of the amplification of ZIKV RNA by NASBA in water, followed by nanoswitch detection (fig. S15). To mimic clinical samples, we spiked infectious ZIKV particles into either phosphate-buffered saline (PBS) or $10 \%$ human urine at clinical-levels (897 $\mathrm{pfu} / \mu \mathrm{l}$ to $20 \mathrm{pfu} / \mu \mathrm{l})$. From these samples our assay detected ZIKV RNA in $\sim 5$ hours (Fig. $5 \mathrm{~B}$ and fig. S15). We went one step further and showed that our assay can be performed using a commercially available buffer-less gel cartridge (ThermoFisher E-gel) and imaged on a small and potentially portable gel reader (fig. S16). With the help of NASBA amplification, the detection ability of our method has about 1,000fold increase, from sub-pM $\left(\sim 10^{5}\right.$ copies $\left./ \mu \mathrm{l}\right)$ (Fig. $\left.5 \mathrm{~A}\right)$ to sub$\mathrm{fM}\left(\sim 10^{2}\right.$ copies/ $\left.\mu \mathrm{l}\right)$ (fig. S15) and the detection time was reduced from $\sim 13$ hours to $\sim 5$ hours.

With the emerging outbreak of SARS-CoV-2 in January 2020 , we took the opportunity to develop and test our DNA nanoswitches against the new virus. Following a similar strategy as for ZIKV, we identified a target region, developed nanoswitches, and used the NASBA strategy to detect a SARSCoV-2 RNA in $10 \%$ human saliva. Following our ZIKV protocol we validated nanoswitch detection of an in vitro transcript of a short segment of SARS-CoV-2 RNA in $\sim 5$ hours, and cross validated with RT-PCR (fig. S17). Further optimizing the protocol times, we achieved detection of SARS-CoV-2 positive control RNA at a concentration as low as 200 copies/ $\mathrm{\mu l}$ (around the clinical median (35-37)) in about 2 hours (1 hour NASBA, 40 min nanoswitch incubation, $25 \mathrm{~min}$ gel) (Fig. 5C and fig. S18).

Taken together, we demonstrate that programmable DNA nanoswitches can be developed into a robust viral RNA detection platform, that is readily adaptable as we show in the detection of SARS-CoV-2. The platform has key advantages over existing methodologies in terms of selectivity and specificity, as shown in our experiments with ZIKV and closely related DENV, as well as two closely related ZIKV strains. Moreover, DNA nanoswitch viral RNA detection strategy has femtomolar detection limit without an RNA amplification step, and attomolar detection limit when used with amplification. These limits are within a clinically relevant range and therefore our DNA nanoswitch assay together with the bufferless gel cartridge presents a putative diagnostic assay for clinical detection of RNA viruses in low resource areas without significant laboratory infrastructure.

\section{Discussion}

The functionality of our DNA nanoswitches is largely enabled by DNA nanotechnology, which has become a well-established field that uses DNA as a functional material to fabricate nanostructures (38). Biosensing is a particularly promising application of DNA nanotechnology (39), and reconfigurable DNA devices (40) have been demonstrated for the detection of DNA (40), RNA (41), proteins (42), and pH (43). However, most designs are complex and require laborious readout with advanced microscopy that reduces their practicality. A few approaches have overcome this practicality hurdle to provide widely useful solutions to problems in biological imaging (e.g., DNA-PAINT in super-resolution microscopy (44) and DNA scaffolds for NMR (45) and cryo-EM (46)) and biosensing (e.g., detection of lysosomal disorders (47) and mapping cellular endocytic pathways (48)). Our DNA nanoswitches take a reductionist approach, resulting in assays that are robust and sensitive, yet simple to adapt and do not require multiple steps or expensive equipment. With this work, we add virus detection to the existing suite of DNA nanoswitch assays that already includes protein (33) and microRNA (21) detection.

Our simple DNA nanoswitch-based assay for detection of viral RNA overcomes some limitations of currently available methods for clinical detection of RNA viruses in resource-limited areas. These include 1) robust detection without enzymes or equipment, 2) maintaining low-cost and simplicity, and 3) providing specificity and versatility. Surprisingly, the current COVID-19 pandemic has shown us that these problems can affect rich countries as well, with many struggling to have testing outpace viral spread.

The intrinsically high signal of our nanoswitches is enhanced here with a new "target multiplication" strategy where we use viral RNA fragmentation to multiply the number of targets, and thus increase the signal intensity. Using this approach, we reached near-clinical levels of detection in urine without the use of enzyme-mediated amplification strategies. This is of significance because enzymes can be key drivers of assay cost and complexity due to requirements including cold storage/transportation, special buffers and reagents, and strict operating temperatures. These factors make enzymatic assays difficult for field use or for use in low resource areas without modern lab infrastructure. Despite these challenges, most currently available techniques rely on enzyme triggered amplification $(7,17,49)$. For our assay, we demonstrated compatibility and dramatic signal improvement with an optional enzymatic pre-amplification step (Fig. 5B-C). However, we believe that further improvements should enable complete coverage of the clinical range without enzymes. A $30 \mathrm{ml}$ sample of urine from a ZIKV-infected patient would contain from $10^{5}$ to $10^{9}$ copies of viral RNA (50), theoretically surpassing our current detection limit. Efficient sample preparation using a viral RNA extraction kit (Fig. 5A), for example, could facilitate use with our DNA nanoswitch assay. 
Two key features of our approach are simplicity and low cost. Our DNA nanoswitches align with the goals of "frugal science" movement, where cost and accessibility to new technologies are valued alongside typical performance metrics $(51,52)$. Our nanoswitches cost around 1 penny per reaction, can be stored dry at room temperature for at least a month, and could be delivered globally without transportation or biosafety concerns. The assay consists of few steps and can be performed in a matter of hours with limited laboratory needs (fig. S19). Our assay uses a readout by gel electrophoresis, which is relatively inexpensive and already part of the workflow in many labs, which is comparatively simpler than many nanotechnology-based assays involving multiple incubation and wash steps. Improvements to the signal readout could potentially help make this approach even more lab independent. Successful detection with a commercially available buffer-less gel system (fig. S16) takes us a step closer to enabling field deployment of our assay, and sample preparation could be aided by other frugal science approaches such as the "paperfuge" (53) and low-cost thermal cycler (54). If purified viral RNA is used in NASBA, the entire detection could be shortened to two hours with a 30 min NASBA step (17) and a 1-hour nanoswitch detection assay (21).

The programmability of our system makes it versatile for a wide variety of viruses including ZIKV, DENV, and SARSCoV-2 as we have shown. These can be detected with high specificity as we showed for ZIKV and DENV (Fig. 3A-B) and for different strains of ZIKV (Fig. 3C-D), even in a multiplexed fashion. Here we have focused on single-stranded RNA viruses but assays for other RNA or DNA viruses could likely be developed similarly. The fast construction and purification processes can facilitate rapid production of DNA nanoswitches to detect an emerging viral threat, potentially in as little as 1-2 days from knowledge of the target sequences, limited mostly by oligo synthesis turnaround time (Fig. 1B). Due to the low cost of the test, our assay could also be useful for monitoring viral progression over time in patients, or for testing potentially infected insects or animals. Therefore, with future optimization toward point-of-care clinical applications in resource-limiting environments, the platform we describe here has a potential to improve accuracy and ease of diagnosis in humans, non-human vectors, and other animals. Ultimately this can enhance our ability to control spread of infection and more rapidly respond to emerging viral threats including the COVID-19 pandemic, and work toward a reduced death toll and economic burden.

\section{Materials and Methods Construction and purification of nanoswitches}

Oligonucleotides were purchased from Integrated DNA Technologies (IDT) with standard desalting, and the full sequences of all strands is listed in Supplementary materials (table S1 to S10). Nanoswitches were constructed as described previously $(18,21)$. A genomic single-stranded DNA (New England Biolabs M13mp18) was linearized using targeted cleavage with BtsCI restriction enzyme. The linearized ssDNA was then mixed with a molar excess of an oligonucleotide mixture containing backbone oligos and detectors, and annealed from $90^{\circ} \mathrm{C}$ to $20^{\circ} \mathrm{C}$ at $1^{\circ} \mathrm{C} \mathrm{min}-1$ in a T100 Thermal Cycler (Bio-Rad, USA). Following construction, the nanoswitches were purified using liquid chromatography (LC) purification (23) to remove excess oligonucleotides. The concentration of purified nanoswitches were determined by measuring A260 absorbance with a Thermo Scientific NanoDrop 2000.

\section{In vitro transcription (IVT) ofviral RNA}

Plasmids containing the full-length ZIKV (Cambodia FSS13025 strain; pFLZIKV) and DENV-2 (strain 16681, pD2/IC-30P) cDNAs were gifts from Dr. Pei-Yong Shi (University of Texas Medical Branch) and Dr. Claire Huang (Centers for Disease Control), respectively $(24,55)$. pFLZIKV was linearized with ClaI (New England Biolabs, NEB), and pD2/IC-30P was linearized with XbaI (NEB). Digested plasmids were extracted with phenol:chloroform:isoamyl alcohol and then precipitated. Linearized plasmids were in vitro transcribed (Thermo Fisher Scientific) and the resulting viral RNA cleaned by MEGAclear Transcription Clean-Up Kit (Thermo Fisher Scientific). We followed the protocols of these two kits except that we did not heat the purification column in the elution step of the viral RNA because we noticed that high temperature can result in degradation of the viral RNA.

\section{Viral RNA fragmentation test}

Viral RNA was fragmented by using $10 \times$ Fragmentation buffer (NEB) and the recommended protocol. Briefly, the ZIKV RNA obtained from in vitro transcription was mixed with fragmentation buffer ( $1 \times$ final) and then incubated at $94^{\circ} \mathrm{C}$ in a thermal cycler for 1, 3, 6, or 9 min. RNA fragmentation analyzer (Agilent, model 5003) was used to quantify the length distribution of RNA fragments by using the DNF-471 Standard Sensitivity RNA Analysis Kit (Fig. 2B).

\section{Cell culture, ZIKV infections and extraction of total RNA and virus particles}

Human hepatocarcinoma (Huh7) cells were maintained in Dulbecco's modified Eagle's medium (DMEM) (Life Technologies) supplemented with $10 \%$ fetal bovine serum (FBS, VWR Life Science Seradigm), $10 \mathrm{mM}$ non-essential amino acids (NEAA; Life Technologies), and $5 \mathrm{mM}$ L-glutamine (Life Technologies). Cells were passaged once every three days and maintained at $37^{\circ} \mathrm{C}$ with $5 \% \mathrm{CO}_{2}$. Twenty-four hours prior to infection Huh7 cells were seeded into tissue culture plates. The following day, one plate was counted. The other two 
plates were used for mock- and ZIKV-infection, where cells were infected at a multiplicity of infection of one. The original Cambodia and Uganda (MR766) ZIKV stocks were a generous gift from Dr. Brett Lindenbach (Yale School of Medicine). To isolate RNA from mock- and ZIKV-infected cells, media from the cells was aspirated and then the cell monolayer was washed once with ice-cold PBS. Hereafter, the cells in each tissue culture plate were lysed in $1 \mathrm{~mL}$ TRIzol (Invitrogen) and total RNA extracted per the manufacturer's instructions.

For experiments using ZIKV infectious particles in PBS/urine (Fig. 5B), Huh7 cells were infected as described above. At 24 hours post-infection, the cell culture media from ZIKV-infected cells, which contained newly assembled and released virions, was collected and concentrated using Amicon Ultra 15 centrifuge filters. The concentrated virus was then stored at $-80^{\circ} \mathrm{C}$. Plaque assays, as described previously (31), were used to determine the number of infectious particles.

\section{DNA nanoswitch detection}

The total detection sample volume was $10 \mu \mathrm{l}$ with $10 \mathrm{mM}$ $\mathrm{MgCl}_{2}, 1 \times \mathrm{PBS}$, nanoswitch at $100 \mathrm{pM}$ final concentration. Samples were incubated in a thermal cycler with thermal annealing from $40^{\circ} \mathrm{C}$ to $25^{\circ} \mathrm{C}$ at $1^{\circ} \mathrm{C} \mathrm{min}{ }^{-1}$ or room temperature (e.g., the NASBA related detections). Before loading into the gel, the samples were stained by GelRed (Biotium Inc.) at $1 \times$ concentration (or $3.3 \times$ for total RNA detection) and mixed with $2 \mu \mathrm{l} 6 \times$ loading dye (15\% Ficoll with $6.6 \%$ of a saturated bromophenol blue solution in water).

\section{Viral RNA detection}

For the experiment in Fig. $2 \mathrm{C}, 5 \mathrm{ng}\left(\sim 8.5 \times 10^{8}\right.$ copies $) \mathrm{ZIKV}$ RNA was used in $10 \mu$ detection assay. Samples were run in $25 \mathrm{ml} \mathrm{0.8 \%}$ agarose gels, cast from molecular biology grade agarose (Fisher BioReagents) dissolved in 0.5 $\times$ Tris-BorateEDTA (TBE) buffer. For the experiments in Fig. $2 \mathrm{~F}$ and fig. S8, first, all nanoswitches were purified by LC and then their concentrations were determined by measuring A260 absorbance with a Thermo Scientific NanoDrop 2000. Nanoswitch mixtures were made by mixing nanoswitches in equimolar concentrations. The detection reaction volume is $10 \mu \mathrm{l}$ with nanoswitch (100 pM final concentration), $\mathrm{MgCl}_{2}$ (10mM), $1 \times$ PBS and blocking oligos $(200 \mathrm{nM})$. The blocking oligos are short oligos (14 nucleotides) that can prevent the binding of target RNA to the inner surface of plastic tubes (21). Samples were incubated in a thermal cycler with thermal annealing from $40^{\circ} \mathrm{C}$ to $25^{\circ} \mathrm{C}$ over $\sim 12$ hours (at $-0.1^{\circ} \mathrm{C} /$ cycle and $5 \mathrm{~min}$ for each cycle, for a total of 150 cycles).

\section{Detection of viral RNA from total RNA}

First, $500 \mathrm{ng}$ total RNA extracted from uninfected/infected cells was fragmented at $94^{\circ} \mathrm{C}$ for 9 min in $1 x$ fragmentation buffer. Fragmented total RNA was then mixed with nanoswitches $\left(100 \mathrm{pM}, \mathrm{MgCl}_{2}(10 \mathrm{mM})\right.$ and PBS $(1 \times)$, and the mixture was made up to $10 \mu \mathrm{l}$ with nuclease-free water. Samples were then incubated in a thermal annealing ramp from $40^{\circ} \mathrm{C}$ to $25^{\circ} \mathrm{C}$ over $\sim 12$ hours (at $-0.1^{\circ} \mathrm{C} /$ cycle and $5 \mathrm{~min}$ for each cycle, for a total of 150 cycles). After the incubation, samples were stained with GelRed at $3.3 \times$ concentration and incubated at room temperature for $30 \mathrm{~min}$. Before loading the gel, $2 \mu \mathrm{l}$ of $6 \mathrm{x}$ blue loading dye was mixed with each sample, and $10 \mu \mathrm{l}$ sample was loaded to each well. Samples were run in a $0.8 \%$ agarose gel at $65-75 \mathrm{~V}$ for about $70-90 \mathrm{~min}$ in the cold room.

\section{Detection of viral RNA extracted from urine}

For the detection of viral RNA extracted from urine, we first added DNA/RNA shield buffer (included with the Quick-RNA Viral Kit from ZYMO research) into urine and then mixed in the RNA with blocking oligos (200 nM) into $200 \mu \mathrm{l}$ human urine (purchased from Innovative Research, Inc.) to mimic a clinical sample, and performed the RNA extraction immediately. Then, we used Quick-RNA Viral Kit (Zymo research) to extract the viral RNA from the urine. After RNA extraction, we added RNase Inhibitor (final concentration, $1 \mathrm{U} / \mu \mathrm{l}$ ) to the solution. We tested different amounts of ZIKV RNA (Fig. 5A). Here, the amount of human urine can be scaled up as needed according to the protocol of the kit. Finally, the viral RNA was eluted from the filter column by using $15 \mu \mathrm{l}$ nuclease-free water. Then $5 \mu$ l extracted RNA was fragmented at $94^{\circ} \mathrm{C}$ for 9 min by using $0.2 \times$ fragmentation buffer (NEB) before conducting the nanoswitch detection. Here, we lowered the use of fragmentation buffer in the consideration of the small amount of RNA in the extracted sample as we noticed that too much fragmentation buffer could destroy the DNA nanoswitches.

\section{Isothermal amplification by NASBA}

First, we employed the classic NASBA protocol (34) to prove the concept (fig. S15). The $25 \mu$ l one-pot reaction contained 3 $\mu \mathrm{l}$ RNA sample at various concentrations, $0.4 \mu \mathrm{M}$ forward and reverse primers, $8 \mathrm{U}$ AMV Reverse Transcriptase, $50 \mathrm{U}$ T7 RNA Polymerase, 0.1 U RNase H, 40 U RNase Inhibitor (NEB, Murine), $2 \mathrm{mM}$ NTP mix, $1 \mathrm{mM}$ rNTP mix, $12 \mathrm{mM}$ $\mathrm{MgCl}_{2}, 40 \mathrm{mM}$ Tris- $\mathrm{HCl}, 42 \mathrm{mM} \mathrm{KCl}, 5 \mathrm{mM}$ Dithiotreitol (DTT), $15 \%(\mathrm{v} / \mathrm{v})$ dimethyl sulfoxide. The primers were chosen from reference (17). The sample was incubated at $41^{\circ} \mathrm{C}$ for 2 hours in the thermal cycler followed by heating at $94^{\circ} \mathrm{C}$ for $10 \mathrm{~min}$ to deactivate all enzymes. $3 \mu \mathrm{l}$ of the NASBA sample was used in the following DNA nanoswitch detection assay in PCR tubes with $10 \mu \mathrm{l}$ final volumes. After mixing with the DNA nanoswitch and reaction buffer, the mixture was incubated at room temperature for two hours. GelRed (Biotium 
Inc.) at $1 \times$ concentration was added to the detection samples before loading to the $0.8 \%$ agarose gel. The gel was run at room temperature for $45 \mathrm{~min}$ at 75 volts.

For the ZIKV related NASBA experiments, first we spiked the ZIKV infectious particles (starting at $1180 \mathrm{pfu} / \mu \mathrm{l}$ ) into $1 \times$ PBS or $10 \%$ human urine (purchased from Innovative Research, Inc.) to concentrations of 897,200 , and $20 \mathrm{pfu} / \mu \mathrm{l}$. Subsequently, blocking oligo (200 $\mathrm{nM}$ ) was added and the viral RNA was released by heating the samples at $94^{\circ} \mathrm{C}$ for 3 min within $10 \mathrm{ul}$ volume. For the human urine samples, RNase Inhibitor (NEB, Murine) was also added at a concentration of $2 \mathrm{U} / \mu \mathrm{l}$ before heating. After cooling down to room temperature, $0.5 \mu \mathrm{l}$ RNase Inhibitor at $40 \mathrm{U} / \mu \mathrm{l}(\mathrm{NEB}, \mathrm{Mu}-$ rine) was added to $10 \mu \mathrm{l}$ human urine sample to protect the viral RNA. Total volume of each NASBA reaction was scaled down to $6 \mu \mathrm{l}$ which contains $1.25 \mu \mathrm{l}$ Enzyme COCKTAIL (NEC 1-24), $2 \mu \mathrm{l} 3 \times$ buffer (NECB-24), $0.48 \mu \mathrm{l}$ NTPs mix at $25 \mathrm{mM}$, $0.3 \mu \mathrm{l}$ dNTPs mix at $20 \mathrm{mM}, 0.2 \mu \mathrm{l}$ two primers mix at $10 \mu \mathrm{M}$, $0.2 \mu \mathrm{l}$ RNase Inhibitor with $40 \mathrm{U} / \mu \mathrm{l}$ (NEB, Murine) and 1.57 $\mu$ l of viral RNA. The sample was incubated at $41^{\circ} \mathrm{C}$ for 2 hours in the thermal cycler and followed by heating at $94^{\circ} \mathrm{C}$ for 5 min to deactivate all enzymes. Then $1 \mu$ of the NASBA sample was used in the following DNA nanoswitch detection assay in PCR tubes with $10 \mu \mathrm{l}$ final volumes. The assay was finished by incubating at room temperature for two hours. After mixing with GelRed at $1 \times$ concentration and $2 \mu \mathrm{l} 6 \times$ blue loading dye, the detection samples were loaded to the $25 \mathrm{ml} 0.8 \%$ agarose gel which was run in $0.5 \times \mathrm{TBE}$ buffer at $75 \mathrm{~V}$ at room temperature for $45 \mathrm{~min}$.

\section{Detection of SARS-CoV-2 RNA}

A gBlock gene fragment of the SARS-CoV-2 RNA segment (56) was purchased from IDT (table S9). Then, PCR amplification (Qiagen, Taq PCR Core Kit) was used to create more copies with a T7 promoter that was added to the $5^{\prime}$ end of the forward primer. Afterword, dsDNA template was cleaned by the QIAquick PCR Purification Kit (Qiagen). Finally, the SARS-CoV-2 RNA was obtained by in vitro transcription (NEB, HiScribe T7 High Yield RNA Synthesis Kit) and cleaned by MEGAclear Transcription Clean-Up Kit (Thermo Fisher Scientific). RTPCR detection was performed using the Luna Universal OneStep RT-qPCR kit from NEB and following its protocol. $1.5 \mu \mathrm{l}$ RNA sample was used in $20 \mu \mathrm{l}$ reaction mix.

For preparation of human saliva sample, pooled human saliva (purchased from Lee Biosolutions, Inc) was heated at $94^{\circ} \mathrm{C}$ for $3 \mathrm{~min}$ to mimic the process of destroying viral capsid to release the RNA. Then, the SARS-CoV-2 RNA was spiked into diluted saliva (10\%) with blocking oligos ( 200 nM) and RNase Inhibitor $(2 \mathrm{U} / \mu \mathrm{l})$. For the NASBA-based detection of SARSCoV-2 RNA purchased from Twist Biosciences, NASBA kits purchased from Life Sciences Advanced Technologies Inc. were used. Briefly, $3.3 \mu \mathrm{l} 3 \times$ buffer (NECB-24), $1.7 \mu$ l $6 \times$
Nucleotide Mix, $0.4 \mu \mathrm{l}$ two primers mix at $10 \mu \mathrm{M}, 0.25 \mu \mathrm{l}$ RNase Inhibitor with $40 \mathrm{U} / \mu \mathrm{l}$ (NEB, Murine) and $2 \mu \mathrm{l}$ viral RNA sample with different concentrations were mixed first and heated at $65^{\circ} \mathrm{C}$ for $2 \mathrm{~min}$ and then the samples were incubated at $41^{\circ} \mathrm{C}$ and $2.5 \mu \mathrm{l}$ Enzyme COCKTAIL (NEC 1-24) was mixed. The samples were incubated at $41^{\circ} \mathrm{C}$ for $40 \mathrm{~min}$ in the thermal cycler followed by heating at $94^{\circ} \mathrm{C}$ for $5 \mathrm{~min}$ to deactivate all enzymes.

Then, $1 \mu$ of the NASBA amplified RNA sample was used in the following DNA nanoswitch detection assay in PCR tubes with $10 \mu \mathrm{l}$ final volumes. Two nanoswitches were developed and used to target the amplified RNA pieces on two different regions (fig. S18). The assay was finished by incubating at room temperature for $40 \mathrm{~min}$. After mixing with GelRed at $1 \times$ concentration and $2 \mu \mathrm{l} 6 \times$ blue loading dye, the detection samples were loaded to the $25 \mathrm{ml} 0.8 \%$ agarose gel which was run in $0.5 \times$ TBE buffer at $90 \mathrm{~V}$ at room temperature for $25 \mathrm{~min}$.

\section{Gel imaging and analysis}

The detection samples were run in $25 \mathrm{ml} 0.8 \%$ agarose gels unless otherwise noted, cast from molecular biology grade agarose (Fisher BioReagents) dissolved in 0.5× TBE buffer. Typical running conditions were $75 \mathrm{~V}$ for 45 to $70 \mathrm{~min}$ at room temperature or cold room. Samples were mixed with a Ficollbased blue loading dye prior to loading. Imaging was completed on a Bio-Rad Gel Doc XR+ imager with different exposure times based on the brightness of the detection bands. The detection efficiency was analyzed using included Image Lab software (Fig. 2E). The profiles of detection bands were obtained in ImageJ (57) and then their integrated intensities were obtained by using the peak analysis function in Origin (OriginLab Corporation), such as the data presented in Fig. $2 \mathrm{~F}, 4 \mathrm{C}$ and $5 \mathrm{~A}-\mathrm{B}$. Detailed analysis procedure can be found in our previous publication (21). For the E-gel related experiments, we used Invitrogen E-gel agarose system (Thermo Fisher Scientific) and its precast agarose gel (1.0\%, SYBR stained). $10 \mu \mathrm{l}$ of nanoswitch detection sample was loaded to each lane and the gel was run at $48 \mathrm{~V}$ for 1 hour at room temperature. Since the E-gel system does not allow user control of the voltage, we used an external power supply connected with the negative and positive electrodes of the precast agarose gel to supply $48 \mathrm{~V}$.

\section{REFERENCES AND NOTES}

1. K. F. Smith, D. F. Sax, S. D. Gaines, V. Guernier, J.-F. Guégan, Globalization of human infectious disease. Ecology 88, 1903-1910 (2007). doi:10.1890/06-1052.1 Medline

2. R. Sanjuán, M. R. Nebot, N. Chirico, L. M. Mansky, R. Belshaw, Viral mutation rates. J. Virol. 84, 9733-9748 (2010). doi:10.1128/JVl.00694-10 Medline

3. D. A. Steinhauer, J. J. Holland, Rapid evolution of RNA viruses. Annu. Rev. Microbiol. 41, 409-433 (1987). doi:10.1146/annurev.mi.41.100187.002205 Medline

4. H. D. Marston, G. K. Folkers, D. M. Morens, A. S. Fauci, Emerging Viral Diseases: Confronting Threats with New Technologies. Sci. Transl. Med. 6, $253 p s 10$ (2014). doi:10.1126/scitranslmed.3009872

5. K. R. Jerome, Lennette's Laboratory Diagnosis of Viral Infections (CRC Press, 2016) 
6. V. M. Corman, A. Rasche, C. Baronti, S. Aldabbagh, D. Cadar, C. B. Reusken, S. D. Pas, A. Goorhuis, J. Schinkel, R. Molenkamp, B. M. Kümmerer, T. Bleicker, S. Brünink, M. Eschbach-Bludau, A. M. Eis-Hübinger, M. P. Koopmans, J. SchmidtChanasit, M. P. Grobusch, X. de Lamballerie, C. Drosten, J. F. Drexler, Assay optimization for molecular detection of Zika virus. Bull. World Health Organ. 94 880-892 (2016). doi:10.2471/BLT.16.175950 Medline

7. D. Musso, D. J. Gubler, Zika Virus. Clin. Microbiol. Rev. 29, 487-524 (2016). doi:10.1128/CMR.00072-15 Medline

8. D. J. Clark, J. Tyson, A. D. Sails, S. Krishna, H. M. Staines, The current landscape of nucleic acid tests for filovirus detection. J. Clin. Virol. 103, 27-36 (2018). doi:10.1016/i.jcv.2018.03.005 Medline

9. K. James, Immunoserology of infectious diseases. Clin. Microbiol. Rev. 3, 132-152 (1990). doi:10.1128/CMR.3.2.132 Medline

10. L. R. Petersen, D. J. Jamieson, A. M. Powers, M. A. Honein, Zika Virus. N. Engl. J. Med. 374, 1552-1563 (2016). doi:10.1056/NEJMra1602113 Medline

11. W. Dejnirattisai, P. Supasa, W. Wongwiwat, A. Rouvinski, G. Barba-Spaeth, T. Duangchinda, A. Sakuntabhai, V.-M. Cao-Lormeau, P. Malasit, F. A. Rey, J. Mongkolsapaya, G. R. Screaton, Dengue virus sero-cross-reactivity drives antibody-dependent enhancement of infection with zika virus. Nat. Immunol. 17, 1102-1108 (2016). doi:10.1038/ni.3515 Medline

12. C. R. Woods, False-Positive Results for Immunoglobulin M Serologic Results: Explanations and Examples. J. Pediatric Infect. Dis. Soc. 2, 87-90 (2013). doi:10.1093/ipids/pis133 Medline

13. J. V. Lazarus, C. Picchio, J. F. Dillon, J. K. Rockstroh, N. Weis, M. Buti, Too many people with viral hepatitis are diagnosed late - with dire consequences. Nat. Rev. Gastroenterol. Hepatol. 16, 451-452 (2019). doi:10.1038/s41575-019-0177-z Medline

14. M. S. Draz, H. Shafiee, Applications of gold nanoparticles in virus detection. Theranostics 8, 1985-2017 (2018). doi:10.7150/thno.23856 Medline

15. S. Afsahi, M. B. Lerner, J. M. Goldstein, J. Lee, X. Tang, D. A. Bagarozzi Jr., D. Pan, L. Locascio, A. Walker, F. Barron, B. R. Goldsmith, Novel graphene-based biosensor for early detection of Zika virus infection. Biosens. Bioelectron. 100, $85-$ 88 (2018). doi:10.1016/j.bios.2017.08.051 Medline

16. J. S. Gootenberg, O. O. Abudayyeh, J. W. Lee, P. Essletzbichler, A. J. Dy, J. Joung, V. Verdine, N. Donghia, N. M. Daringer, C. A. Freije, C. Myhrvold, R. P. Bhattacharyya, J. Livny, A. Regev, E. V. Koonin, D. T. Hung, P. C. Sabeti, J. J. Collins, F. Zhang, Nucleic acid detection with CRISPR-Cas13a/C2c2. Science 356, 438-442 (2017). Medline

17. K. Pardee, A. A. Green, M. K. Takahashi, D. Braff, G. Lambert, J. W. Lee, T. Ferrante, D. Ma, N. Donghia, M. Fan, N. M. Daringer, I. Bosch, D. M. Dudley, D. H. O'Connor, L. Gehrke, J. J. Collins, Rapid, Low-Cost Detection of Zika Virus Using Programmable Biomolecular Components. Cell 165, 1255-1266 (2016). doi:10.1016/i.cell.2016.04.059 Medline

18. M. A. Koussa, K. Halvorsen, A. Ward, W. P. Wong, DNA nanoswitches: A quantitative platform for gel-based biomolecular interaction analysis. Nat. Methods 12, 123126 (2015). doi:10.1038/nmeth.3209 Medline

19. A. D. T. Barrett, Current status of Zika vaccine development: Zika vaccines advance into clinical evaluation. NPJ Vaccines 3, 24 (2018). Medline

20. A. R. Chandrasekaran, J. Zavala, K. Halvorsen, Programmable DNA Nanoswitches for Detection of Nucleic Acid Sequences. ACS Sens. 1, 120-123 (2016). doi:10.1021/acssensors.5b00178

21. A. R. Chandrasekaran, M. Maclsaac, P. Dey, O. Levchenko, L. Zhou, M. Andres, B. K. Dey, K. Halvorsen, Cellular microRNA detection with miRacles: microRNAactivated conditional looping of engineered switches. Sci. Adv. 5, eaau9443 (2019). doi:10.1126/sciadv.aau9443 Medline

22. R. S. Lanciotti, O. L. Kosoy, J. J. Laven, J. O. Velez, A. J. Lambert, A. J. Johnson, S. M. Stanfield, M. R. Duffy, Genetic and serologic properties of Zika virus associated with an epidemic, Yap State, Micronesia, 2007. Emerg. Infect. Dis. 14, 1232-1239 (2008). doi:10.3201/eid1408.080287 Medline

23. K. Halvorsen, M. E. Kizer, X. Wang, A. R. Chandrasekaran, M. Basanta-Sanchez, Shear Dependent LC Purification of an Engineered DNA Nanoswitch and Implications for DNA Origami. Anal. Chem. 89, 5673-5677 (2017). doi:10.1021/acs.analchem.7b00791 Medline

24. C. Shan, X. Xie, A. E. Muruato, S. L. Rossi, C. M. Roundy, S. R. Azar, Y. Yang, R. B. Tesh, N. Bourne, A. D. Barrett, N. Vasilakis, S. C. Weaver, P.-Y. Shi, An Infectious
cDNA Clone of Zika Virus to Study Viral Virulence, Mosquito Transmission, and Antiviral Inhibitors. Cell Host Microbe 19, 891-900 (2016). doi:10.1016/j.chom.2016.05.004 Medline

25. R. G. Huber, X. N. Lim, W. C. Ng, A. Y. L. Sim, H. X. Poh, Y. Shen, S. Y. Lim, K. B. Sundstrom, X. Sun, J. G. Aw, H. K. Too, P. H. Boey, A. Wilm, T. Chawla, M. M. Choy, L. Jiang, P. F. de Sessions, X. J. Loh, S. Alonso, M. Hibberd, N. Nagarajan, E. E. Ooi, P. J. Bond, O. M. Sessions, Y. Wan, Structure mapping of dengue and Zika viruses reveals functional long-range interactions. Nat. Commun. 10, 1408 (2019). doi:10.1038/s41467-019-09391-8 Medline

26. A.-C. Gourinat, O. O'Connor, E. Calvez, C. Goarant, M. Dupont-Rouzeyrol, Detection of Zika virus in urine. Emerg. Infect. Dis. 21, 84-86 (2015). doi:10.3201/eid2101.140894 Medline

27. E. S. Paixão, M. G. Teixeira, L. C. Rodrigues, Zika, chikungunya and dengue: The causes and threats of new and re-emerging arboviral diseases. BMJ Glob. Health 3 (Suppl 1), e000530 (2018). doi:10.1136/bmjgh-2017-000530 Medline

28. J. Ramos-Castañeda, F. Barreto Dos Santos, R. Martínez-Vega, J. M. Galvão de Araujo, G. Joint, E. Sarti, Dengue in Latin America: Systematic Review of Molecular Epidemiological Trends. PLOS Negl. Trop. Dis. 11, e0005224 (2017). doi:10.1371/journal.pntd.0005224 Medline

29. A. D. Haddow, A. J. Schuh, C. Y. Yasuda, M. R. Kasper, V. Heang, R. Huy, H. Guzman, R. B. Tesh, S. C. Weaver, Genetic characterization of Zika virus strains: Geographic expansion of the Asian lineage. PLOS Negl. Trop. Dis. 6, e1477 (2012). doi:10.1371/journal.pntd.0001477 Medline

30. O. Faye, C. C. M. Freire, A. Iamarino, O. Faye, J. V. C. de Oliveira, M. Diallo, P. M. A. Zanotto, A. A. Sall, Molecular evolution of Zika virus during its emergence in the 20(th) century. PLOS Negl. Trop. Dis. 8, e2636 (2014). doi:10.1371/journal.pntd.0002636 Medline

31. G. Bonenfant, N. Williams, R. Netzband, M. C. Schwarz, M. J. Evans, C. T. Pager, Zika Virus Subverts Stress Granules To Promote and Restrict Viral Gene Expression. J. Virol. 93, e00520-e19 (2019). doi:10.1128/JVI.00520-19 Medline

32. G. Paz-Bailey, E. S. Rosenberg, K. Doyle, J. Munoz-Jordan, G. A. Santiago, L. Klein, J. Perez-Padilla, F. A. Medina, S. H. Waterman, C. G. Gubern, L. I. Alvarado, T. M. Sharp, C. G. Gubern, L. I. Alvarado, T. M. Sharp, Persistence of Zika Virus in Body Fluids - Final Report. N. Engl. J. Med. 379, 1234-1243 (2017). doi:10.1056/NEJMoa1613108 Medline

33. C. H. Hansen, D. Yang, M. A. Koussa, W. P. Wong, Nanoswitch-linked immunosorbent assay (NLISA) for fast, sensitive, and specific protein detection. Proc. Natl. Acad. Sci. U.S.A. 114, 10367-10372 (2017) doi:10.1073/pnas.1708148114 Medline

34. M. E. Gabrielle, V. van der, R. A. F. Schukkink, B. van Gemen, y Schepers, y Klatser, Nucleic acid sequence-based amplification (NASBA) for the identification of mycobacteria. Microbiology 139, 2423-2429 (1993).

35. K. K.-W. To, O. T.-Y. Tsang, C. C.-Y. Yip, K.-H. Chan, T.-C. Wu, J. M.-C. Chan, W.-S. Leung, T. S.-H. Chik, C. Y.-C. Choi, D. H. Kandamby, D. C. Lung, A. R. Tam, R. W.-S Poon, A. Y.-F. Fung, I. F.-N. Hung, V. C.-C. Cheng, J. F.-W. Chan, K.-Y. Yuen, Consistent Detection of 2019 Novel Coronavirus in Saliva. Clin Infect Dis, ciaal49 (2020), doi:10.1093/cid/ciaa149.

36. K. K.-W. To, O. T.-Y. Tsang, W.-S. Leung, A. R. Tam, T.-C. Wu, D. C. Lung, C. C.-Y. Yip, J.-P. Cai, J. M.-C. Chan, T. S.-H. Chik, D. P.-L. Lau, C. Y.-C. Choi, L.-L. Chen, W.M. Chan, K.-H. Chan, J. D. Ip, A. C.-K. Ng, R. W.-S. Poon, C.-T. Luo, V. C.-C. Cheng, J. F.-W. Chan, I. F.-N. Hung, Z. Chen, H. Chen, K.-Y. Yuen, Temporal profiles of viral load in posterior oropharyngeal saliva samples and serum antibody responses during infection by SARS-CoV-2: An observational cohort study. Lancet Infect. Dis. 20, 565-574 (2020). doi:10.1016/S1473-3099(20)30196-1 Medline

37. Y. Pan, D. Zhang, P. Yang, L. L. M. Poon, Q. Wang, Viral load of SARS-CoV-2 in clinical samples. Lancet Infect. Dis. 20, 411-412 (2020). doi:10.1016/S14733099(20)30113-4 Medline

38. N. C. Seeman, DNA in a material world. Nature 421, 427-431 (2003). doi:10.1038/nature01406 Medline

39. M. Xiao, W. Lai, T. Man, B. Chang, L. Li, A. R. Chandrasekaran, H. Pei, Rationally Engineered Nucleic Acid Architectures for Biosensing Applications. Chem. Rev. 119, 11631-11717 (2019). doi:10.1021/acs.chemrev.9b00121 Medline

40. L. Zhou, A. E. Marras, C.-M. Huang, C. E. Castro, H.-J. Su, Paper Origami-Inspired Design and Actuation of DNA Nanomachines with Complex Motions. Small 14, 1802580 (2018). doi:10.1002/smll.201802580 Medline 
41. T. Funck, F. Nicoli, A. Kuzyk, T. Liedl, Sensing Picomolar Concentrations of RNA Using Switchable Plasmonic Chirality. Angew. Chem. 130, 13683-13686 (2018). doi:10.1002/ange.201807029 Medline

42. S. M. Douglas, I. Bachelet, G. M. Church, A logic-gated nanorobot for targeted transport of molecular payloads. Science 335, 831-834 (2012). doi:10.1126/science.1214081 Medline

43. S. Modi, S. M G, D. Goswami, G. D. Gupta, S. Mayor, Y. Krishnan, A DNA nanomachine that maps spatial and temporal $\mathrm{pH}$ changes inside living cells. Nat. Nanotechnol. 4, 325-330 (2009). doi:10.1038/nnano.2009.83 Medline

44. R. Jungmann, M. S. Avendaño, J. B. Woehrstein, M. Dai, W. M. Shih, P. Yin, Multiplexed 3D cellular super-resolution imaging with DNA-PAINT and ExchangePAINT. Nat. Methods 11, 313-318 (2014). doi:10.1038/nmeth.2835 Medline

45. M. J. Berardi, W. M. Shih, S. C. Harrison, J. J. Chou, Mitochondrial uncoupling protein 2 structure determined by NMR molecular fragment searching. Nature 476, 109-113 (2011). doi:10.1038/nature10257 Medline

46. T. G. Martin, T. A. M. Bharat, A. C. Joerger, X. C. Bai, F. Praetorius, A. R. Fersht, H. Dietz, S. H. W. Scheres, Design of a molecular support for cryo-EM structure determination. Proc. Natl. Acad. Sci. U.S.A. 113, E7456-E7463 (2016). doi:10.1073/pnas.1612720113 Medline

47. K. Leung, K. Chakraborty, A. Saminathan, Y. Krishnan, A DNA nanomachine chemically resolves lysosomes in live cells. Nat. Nanotechnol. 14, 176-183 (2019). Medline

48. S. Modi, C. Nizak, S. Surana, S. Halder, Y. Krishnan, Two DNA nanomachines map $\mathrm{pH}$ changes along intersecting endocytic pathways inside the same cell. Nat. Nanotechnol. 8, 459-467 (2013). doi:10.1038/nnano.2013.92 Medline

49. J. S. Gootenberg, O. O. Abudayyeh, M. J. Kellner, J. Joung, J. J. Collins, F. Zhang, Multiplexed and portable nucleic acid detection platform with Cas13, Cas12a, and Csm6. Science 360, 439-444 (2018). doi:10.1126/science.aag0179 Medline

50. E. S. Theel, D. J. Hata, Diagnostic Testing for Zika Virus: A Postoutbreak Update. J. Clin. Microbiol. 56, e01972-e17 (2018). doi:10.1128/JCM.01972-17 Medline

51. G. Whitesides, The frugal way: The promise of cost-conscious science. The Economist: The World in 2012 (2011), p. 154.

52. S. Reardon, Frugal science gets DIY diagnostics to world's poorest. New Sci. 219 20-21 (2013). doi:10.1016/S0262-4079(13)62184-3

53. M. S. Bhamla, B. Benson, C. Chai, G. Katsikis, A. Johri, M. Prakash, Hand-powered ultralow-cost paper centrifuge. Nature Biomedical Engineering. 1, 0009 (2017).

54. G. Wong, I. Wong, K. Chan, Y. Hsieh, S. Wong, A Rapid and Low-Cost PCR Thermal Cycler for Low Resource Settings. PLOS ONE 10, e0131701 (2015). doi:10.1371/journal.pone.0131701 Medline

55. R. M. Kinney, S. Butrapet, G.-J. J. Chang, K. R. Tsuchiya, J. T. Roehrig, N. Bhamarapravati, D. J. Gubler, Construction of infectious cDNA clones for dengue 2 virus: Strain 16681 and its attenuated vaccine derivative, strain PDK-53. Virology 230, 300-308 (1997). doi:10.1006/viro.1997.8500 Medline

56. D. K. W. Chu, Y. Pan, S. M. S. Cheng, K. P. Y. Hui, P. Krishnan, Y. Liu, D. Y. M. Ng, C. K. C. Wan, P. Yang, Q. Wang, M. Peiris, L. L. M. Poon, Molecular Diagnosis of a Novel Coronavirus (2019-nCoV) Causing an Outbreak of Pneumonia. Clin. Chem. 66, 549-555 (2020). doi:10.1093/clinchem/hvaa029 Medline

57. C. A. Schneider, W. S. Rasband, K. W. Eliceiri, NIH Image to Image J: 25 years of image analysis. Nat. Methods 9, 671-675 (2012). doi:10.1038/nmeth.2089 Medline

\section{ACKNOWLEDGMENTS}

We thank Andy Berglund, Carl Shotwell, and Jared Richardson for facilitating use of the RNA fragment analyzer; Darren Yang and Wesley P. Wong for assistance and suggestion on adapting the E-gel system with the nanoswitches; Gabriele Fuchs and Bijan K. Dey for providing comments and suggestions on the experiments and manuscript. Funding: Research reported in this publication was supported by the NIH under award R35GM124720 to K. H. and awards R01GM123050 \& R21Al133617 to C.P. The content is solely the responsibility of the authors and does not necessarily represent the official views of the NIH. Author contributions: K.H. conceived and supervised the project. L.Z., K.H., and C.T.P. designed the experiments. L.Z., A.R.C., J.A.P., S.C., O.L., C.C., and K.H. performed the nanoswitch experiments. G.B., P.B., and C.T.P. carried out the cell culture and total RNA extraction from infected cells. L.Z. developed the tool in Matlab and wrote the first draft of the manuscript. L.Z., A.R.C., J.A.P., C.T.P., and
K.H. co-wrote later drafts of the manuscript. Competing interests: K.H. is an inventor on three patents/patent applications related to this work, filed by the President and Fellows of Harvard College and the Children's Medical Center Corporation (U.S. patent no. 9914958, issued 13 March 2018; U.S. patent application no. 20170369935, published 28 December 2017; and U.S. patent application no. 20180291434, published 11 October 2018). A.R.C. and K.H. are inventors on an additional patent application related to this work, filed by Children's Medical Center Corporation, the Research Foundation for The State University of New York, and the President and Fellows of Harvard College (U.S. patent application no. 20180223344, published 9 August 2018). A.R.C. is also an inventor on one additional patent application related to this work, filed by Vital Biosciences Inc. (US patent application no. 20200150083, published 14 May 2020). L.Z. and K.H. are inventors on an additional patent application related to this work, filed by the Research Foundation for The State University of New York, (U.S. patent application no. 63048563, filed 6 July 2020). All other authors declare that they have no competing interests. Data and materials availability: All data needed to evaluate the conclusions in the paper are present in the paper and/or in the Supplementary Materials. Additional data related to this paper may be requested from the authors.

\section{SUPPLEMENTARY MATERIALS}

advances.sciencemag.org/cgi/content/full/sciadv.abc6246/DC1

Submitted 4 May 2020

Accepted 11 August 2020

Published First Release 21 August 2020

10.1126/sciadv.ms. abc6246 
A

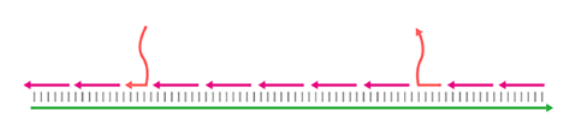

$\longrightarrow$ Scaffold M13 DNA (7249 nt)

$\longleftarrow$ Backbone oligonucleotides (49-60 nt)

$\longleftarrow$ Detectors

B

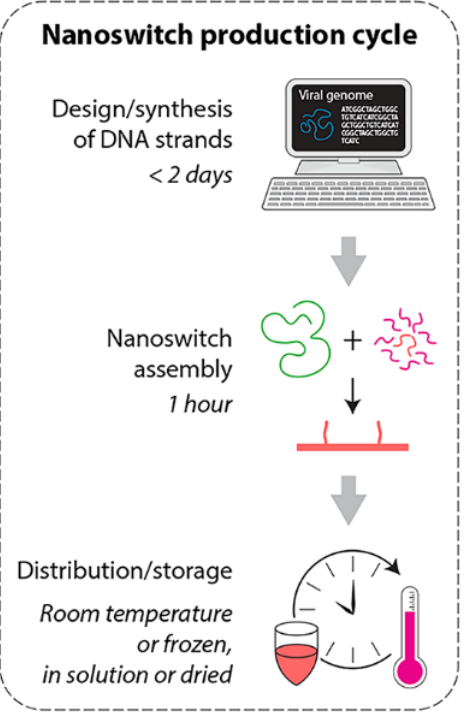

Viral RNA fragments

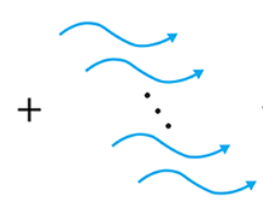

C

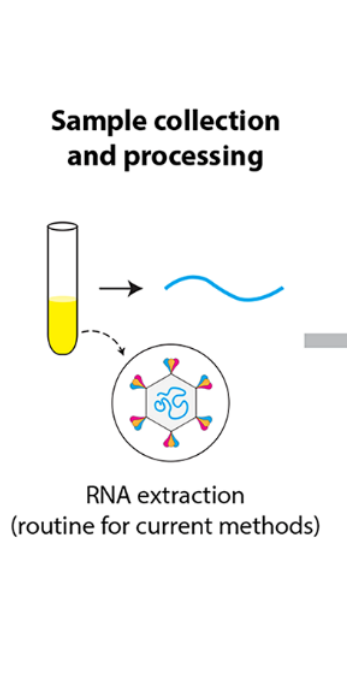

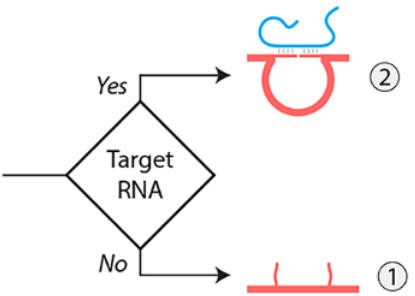

(2)

(1)

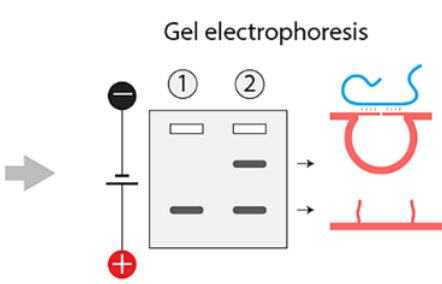

Non-enzymatic detection

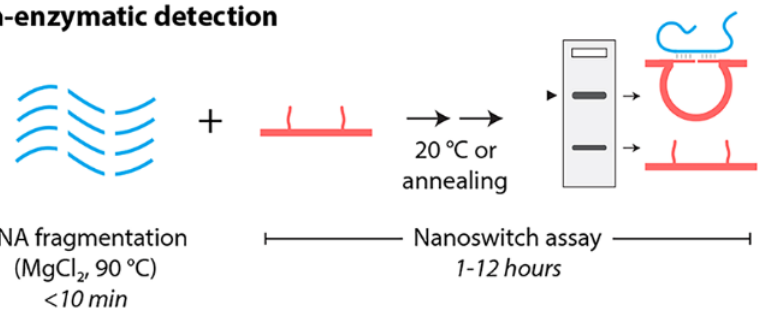

Enzymatic detection

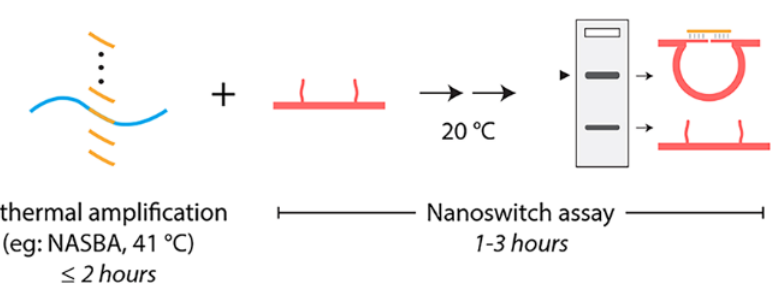

Fig. 1. DNA nanoswitch strategy for viral RNA sensing. (A) Schematic of the DNA nanoswitch and detection of a viral RNA sequence. (B) Fast development cycle of nanoswitches for RNA viruses. (C) Nanoswitch-based assay allows direct detection using a non-enzymatic approach (top panel) and can optionally be combined with an isothermal amplification step like NASBA: nucleic acid sequence-based amplification (bottom panel). 
A

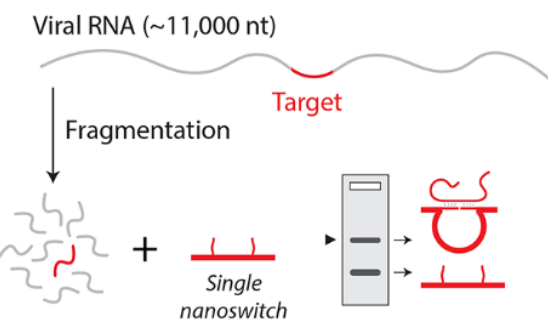

D

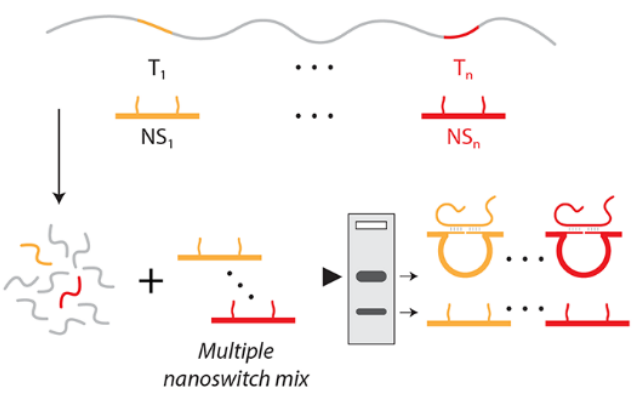

B

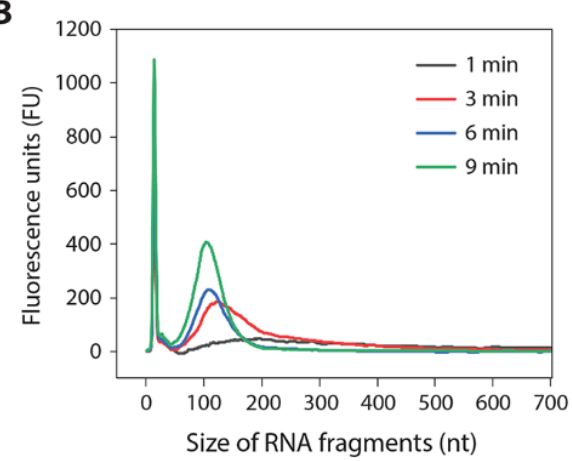

E

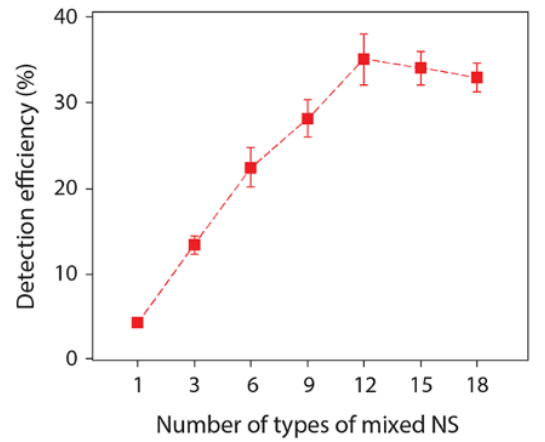

C

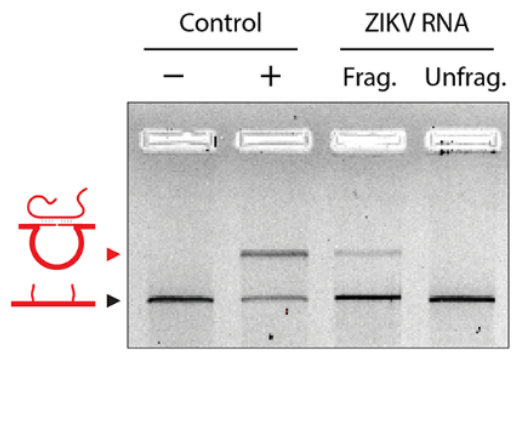

Concentration of ZIKV RNA [ $\times 10^{5}$ copies $\left./ \mu \mathrm{l}\right]$

$\begin{array}{llllll}17.1 & 8.5 & 4.3 & 2.1 & 1.1 & 0.5\end{array}$

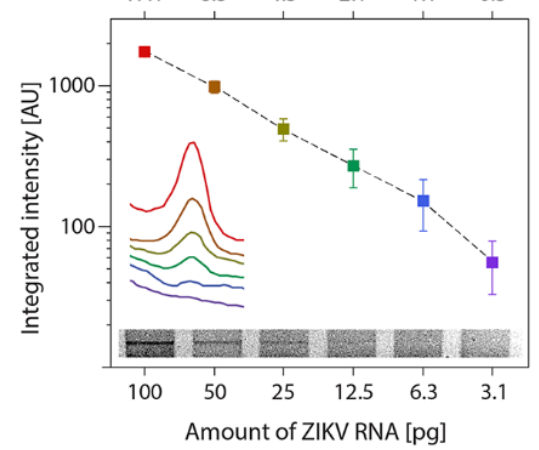

Fig. 2. Detection of viral RNA using DNA nanoswitches. (A) Schematic of the fragmentation of viral RNA and subsequent detection by the DNA nanoswitch. (B) Fragmentation analysis of ZIKV RNA that was fragmented at $94^{\circ} \mathrm{C}$ for $1,3,6$, and 9 min. (C) Proof-of-concept showing detection of a target region chosen from the literature (22) (0.8\% agarose gel in 0.5× TBE buffer). (D) Schematic of the design of multiple nanoswitches for detection with the signal multiplication strategy. (E) Validation of the signal multiplication strategy: the detection signal was increased for a fixed pool of DNA targets when using multiple targeting nanoswitches. (F) Detection sensitivity of the pooled nanoswitches for ZIKV RNA in $10 \mu \mathrm{l}$ reaction. Error bars represent standard deviation from triplicate experiments. 
A Zika nanoswitch

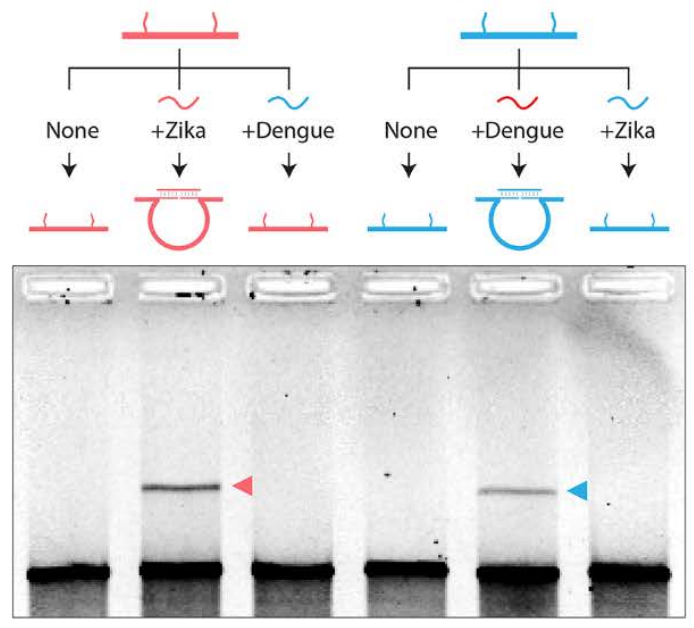

B

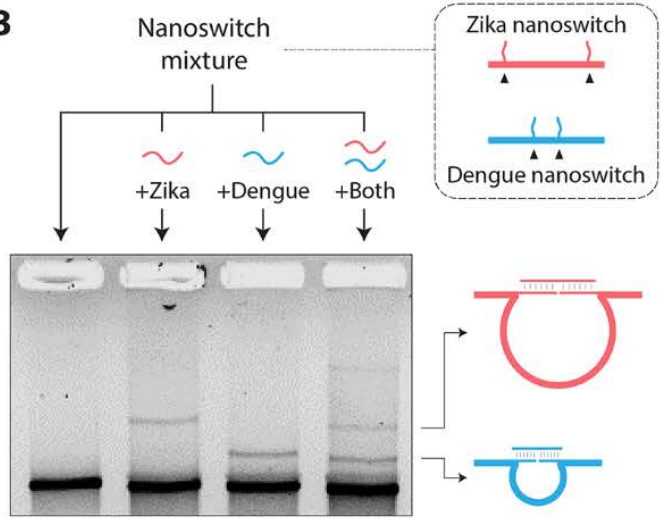

C
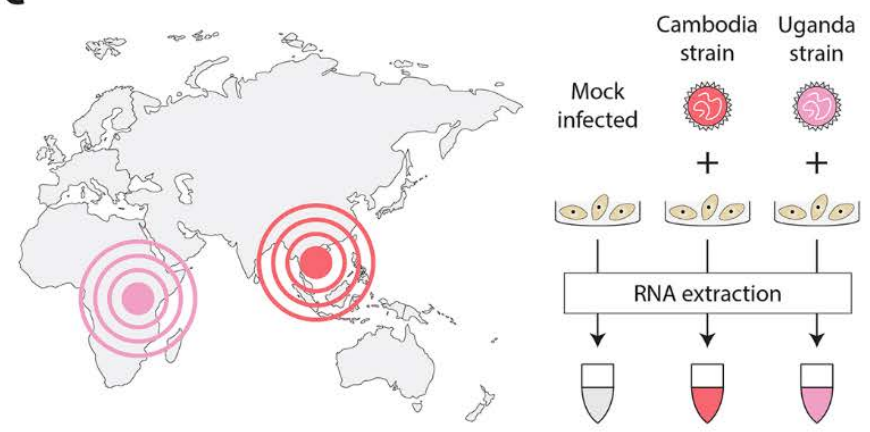

Cambodia: CUCCUAACAUGAAAAUCAUCGGCAGGCGCA Uganda: CUCCCAACAUGAAGAUCAUUGGUAACCGCA

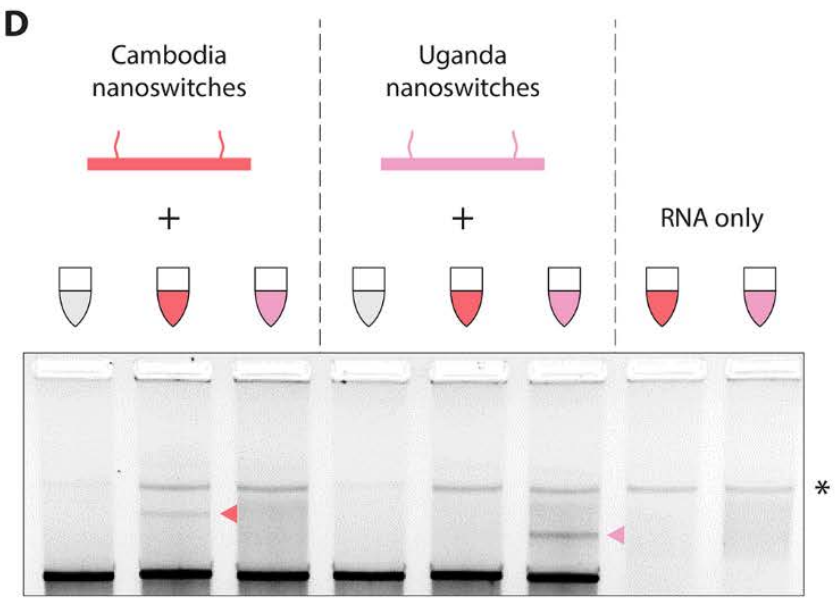

Fig. 3. DNA nanoswitches specifically and differentially detect RNA from two different flaviviruses and between two highly similar ZIKV isolates. (A) ZIKV nanoswitches specifically detect ZIKV RNA but not DENV RNA, and vice versa. (B) Multiplexed detection of ZIKV and DENV RNA. (C) Illustration showing culture and RNA extraction of ZIKV Cambodia and Uganda strains. The mismatches in a representative target sequence between the two strains are shown. (D) Specificity test of Cambodia and Uganda strains of ZIKV RNA. * denotes a band of contaminating cellular DNA following RNA isolation. 
A
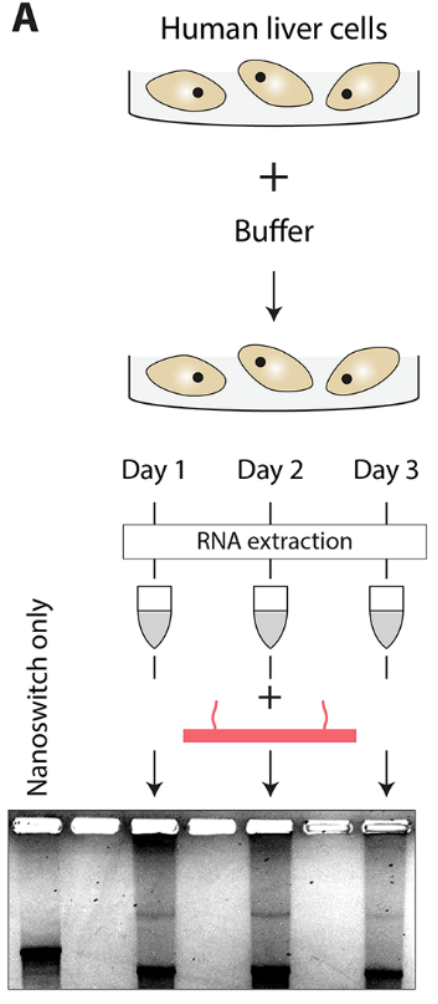

B
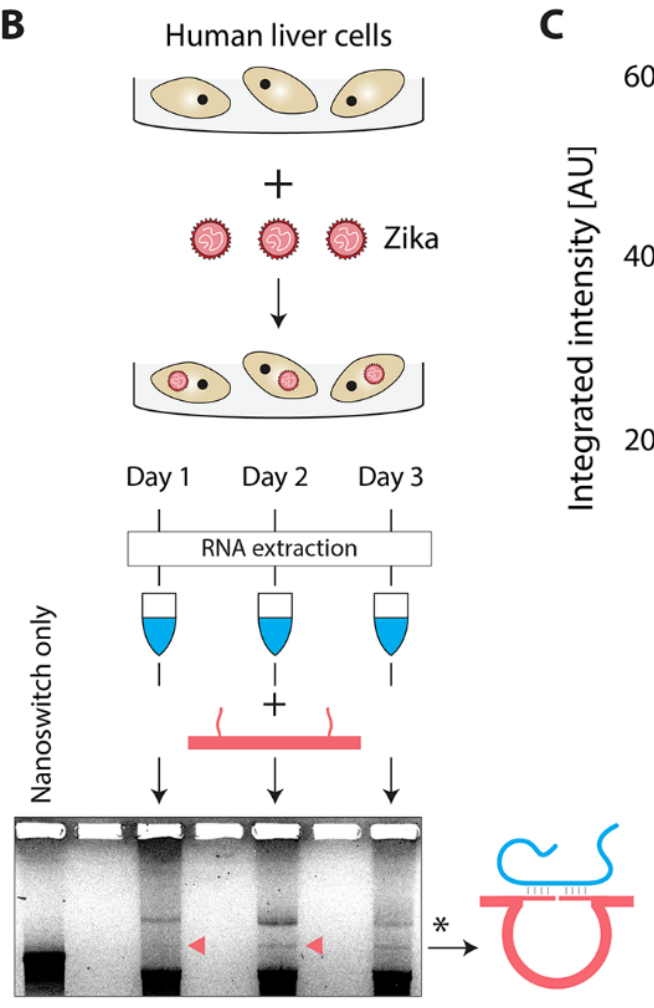

C

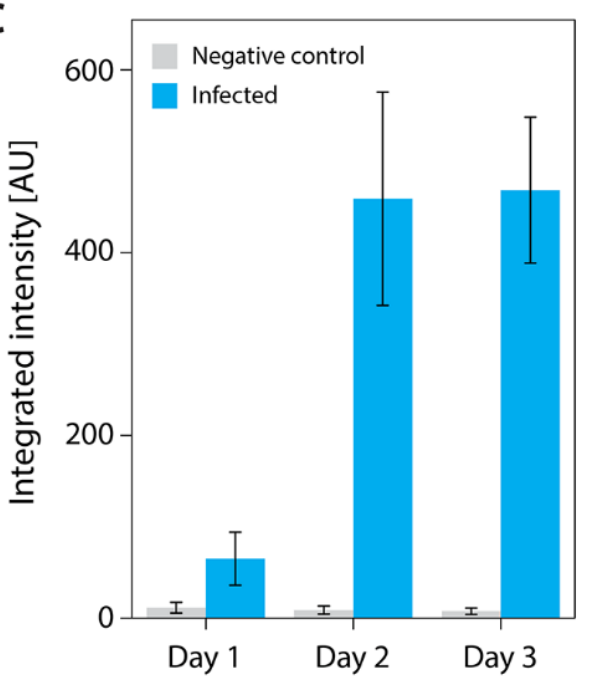

Fig. 4. DNA nanoswitches directly detect ZIKV RNA extracted from infected human liver cells. (A) RNA isolated from mock-infected Huh7 cells at 1, 2, and 3 days post infection shows no ZIKV detection. (B) RNA isolated from Zika-infected Huh7 cells at 1, 2, and 3 days post infection shows increasing detection of ZIKV RNA over time, with red arrows denoting detection bands. * denotes a band of contaminating cellular DNA following RNA extraction. (C) Quantification of nanoswitch detection signal, with error bars representing standard deviation from triplicate experiments. 
A
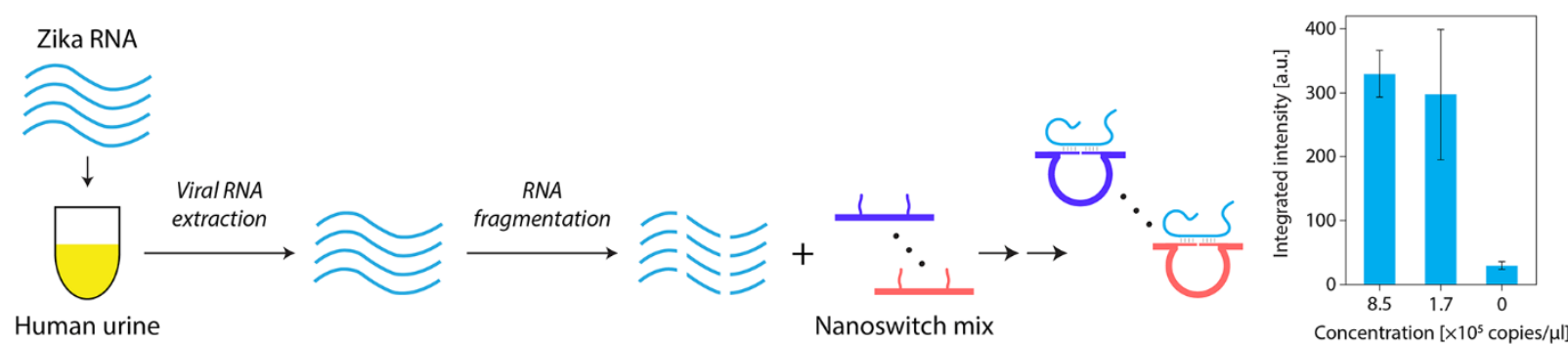

Human urine

Nanoswitch mix

Concentration $\left[\times 10^{5}\right.$ copies $\left./ \mu l\right]$

B
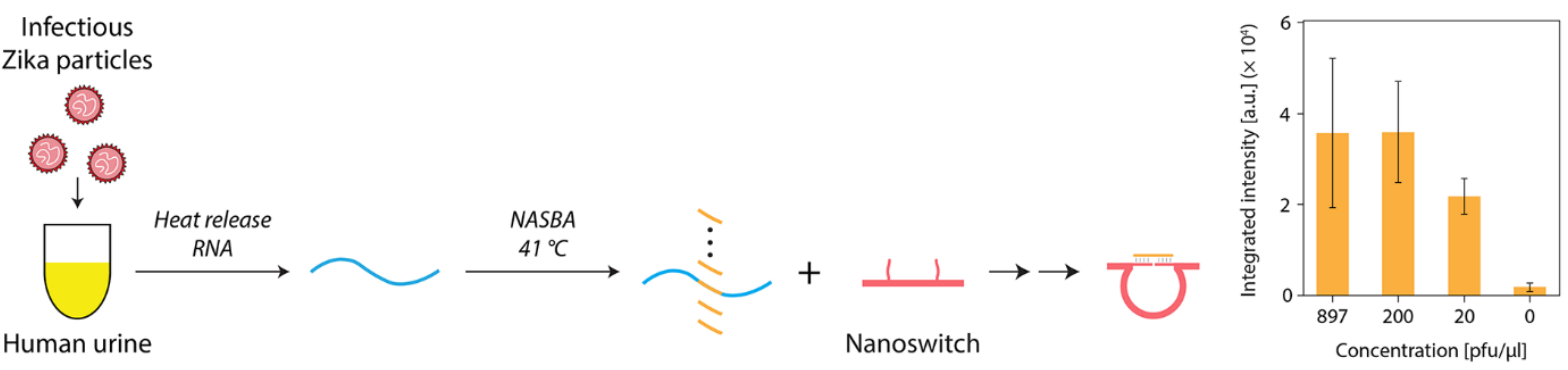

C

SARS-COV-2 RNA

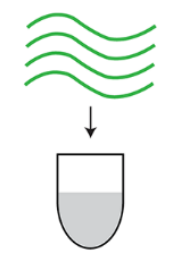

Human saliva

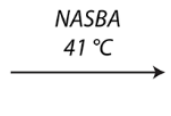

$41^{\circ} \mathrm{C}$<smiles>CC#CC</smiles>

Nanoswitch

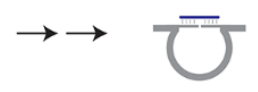

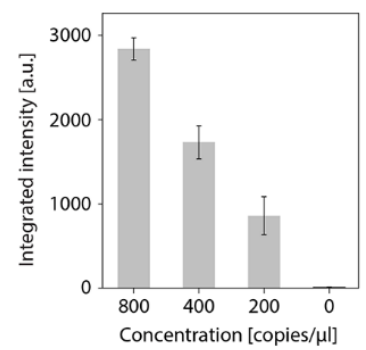

Fig. 5. Prior extraction or pre-amplification of target RNA facilitates detection of ZIKV and SARSCoV-2 RNA at clinically relevant levels in biofluids. (A) Positive identification of ZIKV RNA in spiked urine by first isolating in vitro transcribed target RNA using a commercially available viral RNA extraction kit, followed by direct, non-enzymatic detection using DNA nanoswitches. (B) Positive identification of ZIKV RNA from virus particles spiked into urine based on NASBA. (C) Positive detection of in vitro transcribed SARS-CoV-2 RNA in human saliva based on NASBA. Error bars represent standard deviation from triplicate experiments. 